\title{
The Labour Party leadership election: The Stark model and the selection of Keir Starmer
}

\section{Timothy Heppell ${ }^{1}$}

Accepted: 27 January 2021 / Published online: 24 February 2021

(c) The Author(s), under exclusive licence to Springer Nature Limited 2021, corrected publication 2021

\begin{abstract}
This article considers the selection of Keir Starmer as the new Leader of the Labour Party within the context of the Stark model for explaining leadership election outcomes. The article seeks to achieve three objectives. First, to provide an overview of the nomination stages and the candidates who contested the Labour Party leadership election. Second, to provide an analysis of the underlying academic assumptions of the Stark model on leadership selection and to assess its value as an explanatory model. Third, to use opinion-polling evidence to consider the selection of Starmer in relation to the criteria of the Stark model-i.e. that party leadership (s)electorates are influenced by the following hierarchy of strategic goals: acceptability or select the candidate most likely to unify the party; electability or select the candidate most likely to expand the vote base of the party; and competence or select the candidate most likely to be able to implement their policy objectives.
\end{abstract}

Keywords Keir Starmer · Labour Party · Leadership elections · Leaders of the opposition · Parliamentary Labour party $\cdot$ Labour Party unity

\section{Introduction}

This article contributes to the academic literature on leadership elections within the British Labour Party by profiling the leadership election of 2020. There is a long tradition of academics offering agency-driven accounts of Labour Party leadership elections-i.e. profiling the candidates and the campaigning period, before offering explanations as to who won and why by examining their bases of support and their mandate to lead (Drucker 1976, 1984; Alderman and Carter 1993, 1995; Heppell 2010a, b; Heppell et al. 2010; Heppell and Crines 2011; Dorey and Denham 2011, 2016; Quinn 2016; Crines et al. 2018; Heppell and McMeeking 2021). Alongside these agency-driven accounts are more institutionally orientated analyses, which

Timothy Heppell

T.Heppell@leeds.ac.uk

1 School of Politics and International Studies, University of Leeds, Leeds LS2 9JT, UK 
have concentrated on the importance of the rules for selecting the party leader, including debates on nomination procedures; ejection procedures; membership participation and the trade union link (Drucker 1981; Alderman and Carter 1994; Quinn 2002, 2004, 2005, 2010, 2018; Jobson and Wickham-Jones 2011; Pemberton and Wickham-Jones 2013; Wickham-Jones 2014; Bennister and Heppell 2016; Johnston et al. 2016).

Within the academic literature on leadership selection within the Labour Party, the model advanced by Leonard Stark (1996), focussing on candidate acceptability, electability and competence, has repeatedly been cited in terms of explaining who won and why (see for example, Heppell 2010a; b; Heppell et al. 2010; Heppell and Crines 2011; Dorey and Denham 2011, 2016; Quinn 2012, 2016; Denham and Dorey 2018; Denham et al. 2020). The utility and objectivity of the Stark model has been questioned, however, in a recent paper in British Politics by Maiguashca and Dean (2020) as part of their wider critique about the biases inherent within political science research on British politics (see also Allen 2020; Allen and Moon 2020).

This article uses the Labour Party leadership election of 2020 as a case study through which to test the legitimacy of their critique in relation to the Stark model. In doing so, the paper will be broken down into the following three sections. The first section will provide an analysis of how the leadership election was conductedi.e. profiling the nomination stages and assessing the perceived strengths and weaknesses of the candidates. The second section will explain the criteria of the Stark model-acceptability, electability and competence-and it will explore its potential value (and limitations). Having identified the contribution of the Stark model to academic debates on leadership elections within British politics, the third and final section will exploit opinion polling —on both the membership who participated in the leadership election (whose support they already have as their core vote) and opinion-polling data on the wider electorate (whose support they need to acquire to regain power) - in order to determine whether the Stark model has explanatory value in the case of the selection of Starmer.

\section{Nominations and the leadership ballot}

The Labour Party leadership election of 2020 was triggered by the resignation of Jeremy Corbyn in the aftermath of defeat at the General Election of December 2019. Contested against the backdrop of the dilemma of whether to exit the European Union and to respect the outcome of the referendum of 3 years earlier, ${ }^{1}$ and

\footnotetext{
1 The parliamentary logjam over Brexit and the governmental paralysis of the 2017-2019 Parliament undermined the governing Conservatives, but it failed to translate into increased support for the opposition (Russell 2020; Goes 2020). The starkest realisation of this was the performance of the two main parties in the European Parliamentary Elections of May 2019. The Conservatives finished fifth on 8.8 percent of the vote, as they haemorrhaged support to the newly formed Brexit Party, whose promise of a hard Brexit based on World Trade Organisation rules saw them finish first on 30.5 percent of the vote. However, the Labour Party vote also fell to 13.6 percent and they were in third place behind the Liberal Democrats on 19.6 percent (Cutts et al. 2019).
} 
if so how, the Labour Party struggled to hold together their coalition of remain and leave leaning supporters (Cutts et al. 2020). They were unable to match, or improve upon, their performance in the General Election of 2017, as their vote dropped from $12,878,460$ to $10,269,510$ (their vote share fell from 40.0 to $32.1 \%$ ) and their parliamentary representation fell to their lowest level since the General Election of 1935 , as they returned only 202 seats (Cutts et al. 2020; Goes 2020). Corbyn signalled his intention to step aside within hours of the exit poll, in the early hours of December 13 th, setting off the fight for the succession.

The deadline for nominations from within the parliamentary Labour Party (PLP) was set at January 13th (stage one); the deadline for nominations from within constituency Labour parties (CLPs) and trade union affiliates was set at February 15th (stage two); and the Labour Party selectorate received their postal ballot and online voting forms (stage three) on February 24th. Voting closed on April 2nd with the outcome of the ballot declared on April 4th (Bush 2020).

Stage one of the nomination process stipulated that candidates would need to be nominated by at least ten percent of the current (PLP $n=202$ ) and the European Parliamentary Labour Party (EPLP) $n=10$, making the threshold for participation 22 (Bush 2019). Clive Lewis, the shadow Treasury minister, withdrew his candidature just prior to the deadline, meaning that a total of five candidates proceeded having passed the nomination threshold. From the backbenchers, were the candidatures of Jess Phillips (23 nominations) and former shadow Energy Secretary, Lisa Nandy (31 nominations). From within the Corbyn shadow Cabinet came the candidatures of the shadow Foreign Secretary, Emily Thornberry (23 nominations); the shadow Business Secretary, Rebecca Long-Bailey (33 nominations), and the shadow Brexit Secretary, Starmer (86 nominations) (Labour Party 2020a). Starmer had the momentum of being backed by $41.5 \%$ of his fellow parliamentarians and held a significant lead over Long-Bailey (16\%) and Nandy (14.5\%) as the candidates proceeded to stage two of the leadership election (at this stage, Phillips withdrew her candidature) (Rea 2020).

Stage two involved securing the nominations of CLPs and affiliated trade unions, with candidates needing to secure the backing of at least five percent of CLPs (i.e. 33 ), or at least three affiliates which would include at least two trade unions that together represented over five percent of affiliated members (Bush, 2019). Of the 641 CLPs (out of 648) who indicated their preference, Starmer secured 374 nominations (57.7\%); Long-Bailey 164 nominations (25.3\%); and Nandy 72 nominations (11.1\%). Thornberry was eliminated as she failed to pass the nominations threshold-she had the backing of 31 CLPs or $4.8 \%$. Amongst nominations from the affiliates Thornberry secured no backers, whereas Starmer secured the support of 15 (out of 32 affiliates), Long-Bailey secured the backing of seven and Nandy was supported by four (Labour List 2020).

Stage three was a one-person (member, registered and affiliated supporter) onevote ballot and involved a campaigning period which was to last for 6 weeks. This would generate considerably less media attention than normal due to the onset of the coronavirus pandemic. As they proceeded to the actual ballot, the characterisation of the three candidates was clearly established and it remained largely unchanged throughout the campaign. Securing the endorsement of Momentum confirmed that 
Long-Bailey was the continuity Corbyn candidate (Maguire 2020a). Her alignment to the Corbynite agenda was long standing: she nominated and voted for him in both the 2015 and 2016 Labour Party leadership elections and she remained loyal to him when other members of the shadow frontbench resigned in July 2016 (Syal et al. 2016). That Long-Bailey was a Corbynite was also confirmed from the findings of the loyalty list, drawn up by members of the Corbyn inner circle in March 2016, and leaked to the Guardian. Each Labour parliamentarian was positioned on a spectrum of loyalty with a neutral grouping in the centre $(n=71)$ alongside loyalists to the left $(n=75)$ and critics to the right $(n=85)$. Those left-right groupings had further subdivisions within them. The left was subdivided into the truly loyal core group who believed in the Corbyn project $(n=19)$ and a core group plus $(n=56)$, made up of those who could work with the Corbyn leadership. The critics on the right were also subdivided into two groupings-i.e. core group negative $(n=49)$ and hostile $(n=36)$. Long-Bailey was identified as one of the nineteen in the core group of Corbynites (Asthana and Stewart 2016).

The leaked list positioned both Nandy and Starmer on the left of the spectrum and within the core group plus grouping (alongside Thornberry) (Asthana and Stewart 2016). They took alternative routes during the Corbyn era thereafter, although both of them partook in the mass resignations of July 2016 which were designed to force Corbyn to resign (Syal et al. 2016). Nandy remained on the backbenchers thereafter and became a critic of the leadership capability of Corbyn, notably in relation to the tribalism that existed during his leadership tenure and his handling of the antisemitism crisis (Walker 2020). Nonetheless, she campaigned as an anti-austerity candidate who aimed to reconnect the party to their lost voters from the red wall of traditional northern and midland constituencies (Nandy 2020). She claimed that she could do so because she was a northern Labour parliamentarian, who was one of the nineteen members of the PLP who eventually voted for the Withdrawal Agreement in October 2019, having argued that Parliament should respect the result of the referendum (HC Deb, Vol. 666, Col. 917-20, 22 October 2019). Given that remain sentiment was dominant within the party membership (Bale et al. 2020, pp. 66-68), her acceptance of the decision to leave (although she voted remain and was a defender of free movement) was always going to be problematic for her (Jones 2020).

Starmer was ideologically enigmatic. He was initially positioned in the core group plus grouping in the leaked list in March 2016, and during the leadership campaign, he made it clear that he was an advocate of many aspects of the Corbynite agenda-e.g. challenging austerity; abolishing tuition fees; and bringing water, rail, mail and energy under public ownership (Maguire 2020b; Fielding 2020). Yet he did resign from the frontbench in July 2016. Whereas so many of those who resigned languished on the backbenchers thereafter-either refusing to serve and not being asked back-Starmer turned this into an opportunity for his own career advancement. He was willing to serve again and by late 2016 Corbyn had appointed him to the high-profile role of shadow Brexit Secretary. This was potentially helpful for him in terms of developing his reputation in preparation for a hypothetical post-Corbyn leadership succession contest-i.e. it enabled him to showcase his political ability to a remain leaning movement by critiquing and undermining the efforts of the May and Johnson administrations on Brexit. It was also potentially problematic for 
Table 1 The result of the Labour Party leadership election of 2020

\begin{tabular}{|c|c|c|c|}
\hline & \multicolumn{3}{|l|}{ Candidates } \\
\hline & Keir Starmer & $\begin{array}{l}\text { Rebecca Long- } \\
\text { Bailey }\end{array}$ & Lisa Nandy \\
\hline \multicolumn{4}{|c|}{ Party members } \\
\hline Votes & 225,135 & 117,598 & 58,788 \\
\hline Percentage & 56.1 & 29.3 & 14.6 \\
\hline \multicolumn{4}{|c|}{ Registered supporters } \\
\hline Votes & 10,228 & 650 & 2,128 \\
\hline Percentage & 76.6 & 5.0 & 17.4 \\
\hline \multicolumn{4}{|c|}{ Affiliated supporters } \\
\hline Votes & 40,417 & 16,970 & 18,681 \\
\hline Percentage & 53.1 & 22.3 & 24.6 \\
\hline \multicolumn{4}{|l|}{ Total } \\
\hline Votes & 275,780 & 135,218 & 79,597 \\
\hline Percentage & 56.2 & 27.6 & 16.2 \\
\hline
\end{tabular}

Turnout: $62.6 \%$

Source Labour Party (2020b)

him. It left him somewhat tainted by the accusation that he was one of the architects of the manifesto commitment of a confirmatory referendum, a position which contributed to them losing a number of leave leaning constituencies (Cutts et al. 2020). His unwillingness to criticise the Corbyn era might have been calculated to appease potential Long-Bailey supporters who had doubts about his convictions. And maybe these reassurances were necessary: not only was he was willing to participate in the mass resignations; he voted for Andy Burnham and then Owen Smith in the Labour Party leadership elections of 2015 and 2016, respectively; and he voted in favour of Trident renewal in 2016 (Heppell 2020).

Despite these reservations, Starmer was to secure a comfortable victory as evident in Table 1. Starmer secured an overall support level of $56.2 \%$, which was broken down into $56.1 \%$ of party members; $53.1 \%$ of affiliated supporters; and $76.6 \%$ of registered supporters. The next two sections of the paper consider first, the Stark model and, second, its value in terms of explaining the selection of Starmer.

\section{The Stark model}

The central rationale of the Stark model is that the party (s)electorate, whether they are using parliamentary ballots, all-member ballots, hybrid parliamentary-membership ballots or electoral colleges using delegates or individual members, will be motivated by the goal of securing governmental power as a consequence of electoral success (Stark 1996).

Exploiting the work of Sjoblom (1968) on what motivates parties within parliamentary systems, Stark constructed his hierarchy of strategic goals for parties when selecting their next party leader-see Table 2 below. The first strategic goal will be 
Table 2 Strategic goals and selection criteria in leadership elections

\begin{tabular}{llll}
\hline Order & Arena & Goal & Criterion \\
\hline First & Internal & Unity & Acceptability \\
Second & Electoral & Victory & Electability \\
Third & Parliamentary & Policy & Competence \\
\hline
\end{tabular}

Source Adapted from Stark (1996, p. 126), Quinn (2012, p. 12)

to secure internal unity-i.e. the leader selected must pass the unity-acceptability test so that they can then present the party as a viable candidate for office at the next general election. The second strategic goal flows from the first-i.e. as the party moves into the electoral arena, where the goal is voter maximisation, then the leader with the greatest voter appeal would be deemed the most logical choice. The Stark model comes across as sequential—once the party has addressed the first-order issue of unity-acceptability, by eliminating the most divisive candidate(s) - they then move onto the selecting the most electorally appealing, with this assumed to be influenced by opinion-polling evidence. The third strategic goal, arrived at having eliminated the ideologically divisive and less popular candidates, will be to select the candidate who is perceived to be the most competent-i.e. they will identify the candidate who could be the most effective Leader of the Opposition or Prime Minister. This reflects the desire to effectively implement policy (once in office) with the consequence of effective policy implementation and governmental competence being re-election (Stark 1996, pp. 125-126).

When applying the criteria of the Stark model, the challenge has been (a) how to determine which candidate is superior in relation to each of the criteria and (b) how to explain outcomes when the most superior candidate differs depending on which criteria is being considered?

On the first challenge, it could be argued that the judgements being made are unmeasurable and thereby subjective. However, qualitative insights can be gathered from interviews from within the campaign teams of the different candidates and their support bases, and these can be supplemented with descriptive quantitative insights derived from opinion-polling data about the respective candidates (Stark 1996; Quinn 2012, 2016; Heppell 2010a; Denham et al. 2020).

On the second challenge, Table 3 below suggests that there are some leadership elections in which it appears clear that one candidate is superior in all three criteria-e.g. 1963, 1976, 1988, 1992 and 1994 (for profiles of these leadership elections, see Drucker 1976; Alderman and Carter 1993, 1995; Heppell 2010a, 2010b; Heppell et al. 2010). When the most superior candidate differs across the three criteria of acceptability, electability and competence, then the first-order criteria of unity acceptability takes precedence. This applied to the Labour Party leadership elections of 1980, 1983 and 2010-see Table 3. In these leadership elections, Denis Healey, Roy Hattersley and David Miliband were stronger candidates in terms electability and perceived competence (as compared to Michael Foot, Neil Kinnock and Ed Miliband), but they were defeated because their opponents were deemed to 
Table 3 Labour Party leadership successions 1963-2010

\begin{tabular}{lllllll}
\hline Year & Electorate & Winner & Criteria & & & Key \\
\cline { 4 - 6 } & & & Acceptability & Electability & Competence & Criteria \\
\hline 1963 & MPs & Wilson & Wilson & Wilson & Wilson & All \\
1976 & MPs & Callaghan & Callaghan & Callaghan & Callaghan & All \\
1980 & MPs & Foot & Foot & Healey & Healey & Acceptability \\
1983 & Electoral College* & Kinnock & Kinnock & Hattersley & Hattersley & Acceptability \\
1988 & Electoral College* & Kinnock & Kinnock & Kinnock & Kinnock & All \\
1992 & Electoral College* & Smith & Smith & Smith & Smith & All \\
1994 & Electoral College** & Blair & Blair & Blair & Blair & All \\
2007 & Uncontested $* * *$ & Brown & - & - & - & - \\
2010 & Electoral College** & E Miliband & E Miliband & D Miliband & D Miliband & Acceptability \\
\hline
\end{tabular}

*Electoral College Block Vote Rules 1981-1993

**Electoral College OMOV Rules 1993-2014

***Gordon Brown was the only candidate to pass the nomination thresholds for entry and thus he was automatically elected leader of the Labour Party without activating the Electoral College

Sources Adapted from Stark (1996), Quinn (2012), Denham and Dorey (2018)

be superior in the first-order criteria of unity-acceptability (see Stark 1996; Quinn 2012; Denham and Dorey 2018).

The Stark model has been widely cited in studies not only on the Labour Party, but also on leadership elections within the Conservative Party as well-(on the Conservatives see Denham 2009a, b, 2010, 2012, 2013, 2017; Heppell 2010a, b; Heppell et al. 2010; Heppell and Crines 2011; Denham et al. 2020; Roe-Crines et al. 2020). In the period since 1963 and covering both the Labour and Conservative parties, only two leaders have been selected who were said to be inferior to others across all three criteria-i.e. Corbyn in winning the Labour Party leadership election of 2015 and Margaret Thatcher in winning the Conservative Party leadership election of 1975 (Quinn 2012, p. 160; Quinn 2016; Denham and Dorey 2016).

Although widely cited the Stark model and its criteria have been subjected to only limited critical analysis. However, as was mentioned in the introduction, Maiguashca and Dean (2020) have questioned the utility and objectivity of the Stark model, arguing that it is constructed on problematical assumptions. Moreover, they suggest that this is reflective of a wider 'Corbyn problem' within political science, a community of scholars which, they claim, advance 'politicised scholarship' in which "normative opposition all too often spills over into un-reflexive and un-rigorous scholarship' (Maiguashca and Dean 2002, pp. 56, 63). From a similar perspective, Allen has spoken of a group of political scientists, who are 'intensely politically motivated individuals', who demonstrated a 'dismissive attitude' towards the Labour Party under Corbyn (Allen, 2020; see also Allen and Moon 2020).

In questioning the Stark model, Maiguashca and Dean challenge the criteria that are used and how they are interpreted. When discussing acceptability, they ask acceptable to whom - the parliamentary party or the wider membership? When discussing electability, they question the demonising of Corbyn amongst political 
scientists, see for example, Diamond 2016, Bale 2016. They responded by emphasising (a) the increase in their membership from 198,000 to 552,000 between 2015 and 2017 (Whiteley et al. 2019, p. 81) and (b) the increase in their vote between the General Elections of 2015 and 2017, from 9,347,273 votes (30.4\%) to 12,877,860, votes $(40.0 \%)$ (Dorey, 2017). Finally, when discussing competence, they bypassed the extensive academic literature on competence-valence politics; voter choice and leadership effects (see for example, Stewart and Clarke 1992; Clarke and Stewart 1995; Clarke et al. 2000; Clarke et al. 2009; Stevens et al. 2011; see also Denver and Garnett 2012; Whiteley et al. 2013; Clarke et al. 2016) and challenged the narrow definition of what constitutes leadership competence as they praised Corbyn for his ability to intellectually reenergise left politics (Maiguashca and Dean 2020, p. 55). In doing so, they challenged the consensus view that Corbyn was a 'bad' leader (Maiguashca and Dean 2020, p. 55).

However, their critique has been undermined by events. The initial hostility of political scientists towards Corbyn did seem open to question in the immediate aftermath of the General Election of 2017. For example, back in 2016, Dorey and Denham argued that in selecting Corbyn, the Labour Party had made themselves 'ideologically pure but politically impotent' (Dorey and Denham 2016, p. 261), whilst Bale argued that 'Labour cannot possibly win, nor even come close to winning, the next General Election unless it somehow gets shot of Mr Corbyn in pretty short order' before adding that 'if he lasts very much longer as leader then there is every chance that Labour will gift the Tories control of government for a decade or more to come, so great will be the damage done to its already fragile brand' (Bale 2016, p. 18). However, the arguments of Bale and Dorey and Denham seemed more credible in the aftermath of the General Election of December 2019, just as Maiguashca and Dean's (2020) defence of Corbyn was undermined by the fact that doubts about Corbyn's leadership competence had been identified as one of the key reasons why the Labour Party lost support between the General Elections of 2017 and 2019. ${ }^{2}$

Moreover, their critique about political science being biased against the left is problematic when considering the Stark model. After all, the Stark model has been used as a basis around which to explain how and why more leftward leaning candidates have won the Labour Party leadership elections of 1963 and $1980^{3}$ (Heppell 2010c). The more leftish leaning Harold Wilson defeated the social democratic right

\footnotetext{
${ }^{2}$ Of those who voted for the Labour Party in the General Election of 2017 but who defected away from them at the General Election of 2019, the opinion-polling evidence suggested that 16 percent defected due to doubts about their economic competence; 19 percent defected due to concerns about their Brexit policy; and 35 percent abandoned Labour due the leadership of Corbyn (Curtis, 2019). As to why Corbyn had become a liability, this could be attributed to a). the internal factionalism between the Corbynite and non-Corbynite factions, $b$ ). the increasing focus on antisemitism within the party, and c). the tone of the journalistic coverage or media (mis)representations which framed perceptions of Corbyn negatively (see Goes 2020; Philo et al. 2019; Cammaerts et al. 2020).

${ }^{3}$ Studies into leadership selection within the Labour Party tend to define candidates on a spectrum of Labour political thought based on five positions: on the socialist left, either the old left associated with legacy of Nye Bevan or the new left thinking of Tony Benn; the loyalists in the centre; the old right in the tradition of Hugh Gaitskell and the positioning of New Labour and the leadership of Tony Blair - see Plant, Beech and Hickson, 2004, pp. 2-3.
} 
candidate, George Brown, in the 1963 Labour Party leadership election because he was deemed to be more acceptable; more electable and more competent (Heppell 2010a, b). The socialist left Michael Foot defeated the social democratic right candidate, Healey in the 1980 Labour Party leadership election, despite Healey being perceived as more electable and competent; as Foot was more acceptable (Heppell 2010a; Heppell and Crines 2011). In addition, the rejection of David Milibandperceived to be the continuity New Labour candidate - in the Labour Party leadership of 2010 can also be explained by the Stark model. His superiority in terms of electability and competence was trumped by the fact that his younger brother's willingness to transcend aspects of the Blairite past made him more acceptable to parts of the (s)electorate within the Electoral College_-as per the Stark model emphasis on the ordering of the criterion (Dorey and Denham 2011).

Furthermore, if you want to examine the problematical assumptions of the Stark model within a wider debate on political science biases, this does require an understanding of how the Stark model has been applied to studies on Conservative Party leadership elections. As was mentioned earlier, the model fails to explain the selection of Thatcher in the 1975 Conservative Party leadership election-where she was deemed to be inferior to William Whitelaw against all three criteria in the secondround ballot (Quinn 2012, p. 160; see also Cowley and Bailey 2000). This could imply that the model is problematical for the more ideological candidates-either left or right-but it cannot be used to support the argument that the Stark model holds a bias solely against candidates of the ideological left.

Moreover, the Stark model provides scholars with a credible way of explaining the selections in each of the other Conservative Party leadership elections since the onset of democratisation. This includes selections in times when the Conservatives have been riven with internal ideological conflict, and they have selected the most economically liberal and Eurosceptic candidate available to them-i.e. the selections of the more ideologically acceptable candidatures of William Hague and Iain Duncan Smith in 1997 and 2001 over the more electable and competent candidate, which on both occasions was Kenneth Clarke (Alderman and Carter 2002; Heppell and Hill 2008, 2010; Hayton and Heppell 2010).

However, the primary problem with Maiguashca and Dean critique of the Stark model is the evidence which demonstrates that it does help explain the selection of Starmer in the Labour Party leadership election of 2020. The final section of this paper will demonstrate this by considering the candidatures of Starmer, Long-Bailey and Nandy in relation to the opinion-polling evidence that corresponds to the Stark criteria of acceptability (unifying capability); electability and competence.

\section{The Stark model and the Labour Party leadership election of 2020}

The evidence from the opinion polling of those members who participated in the leadership ballot is clear. Pollsters asked the selectorate to compare and contrast the candidates, in relation to a series of questions that captured the themes associated with the Stark model on acceptability, electability and competence (see Table 4, below). 
Table 4 Labour Party leadership electorate 2020 and attitudes towards candidates

\begin{tabular}{llll}
\hline & Starmer & Long-Bailey & Nandy \\
\hline $\begin{array}{l}\text { Acceptability } \\
\quad \text { Could unite the labour party }\end{array}$ & $50 \%$ & $18 \%$ & $27 \%$ \\
$\begin{array}{l}\text { Electability } \\
\text { Could win next general election }\end{array}$ & $63 \%$ & $26 \%$ & $24 \%$ \\
$\begin{array}{l}\text { Competence } \\
\text { Could provide effective opposition }\end{array}$ & $65 \%$ & $34 \%$ & $33 \%$ \\
Understands policy detail & $70 \%$ & $48 \%$ & $37 \%$ \\
A good media performer & $65 \%$ & $33 \%$ & $41 \%$ \\
Would be a strong leader & $59 \%$ & $28 \%$ & $20 \%$ \\
\hline
\end{tabular}

Source YouGov (2020a)

Starmer was clearly viewed as the most unifying of the candidates: he held a $23 \%$ lead over the second most unifying candidate (Nandy). He was also viewed as the most likely to win the next general election: he held a $37 \%$ lead over the next best placed candidate, Long-Bailey. A range of questions relating to competence were asked-i.e. opposition effectiveness; policy expertise; media performance; and leadership strength - and all of them provided Starmer with double-digit leads over his rivals, with his scores ranging from 59 to $70 \%$ on these, whilst his rivals ranged between 20 to $48 \%$ (YouGov 2020a). Moreover, those members who decided to select Starmer did so with an expectation that the image and positioning of the Labour Party would change as compared to the Corbyn era. Opinion polling on the voting selectorate identified how $92 \%$ of participants expected Starmer to make the Labour Party 'different' to the Corbyn era-with 3\% seeing no change, and five percent don't know-as compared to Long-Bailey on $25 \%$ different, $70 \%$ no change and 5\% don't know (Nandy was $80 \%$ change; $9 \%$ no change and $11 \%$ don't know) (YouGov 2020b).

In addition to noting opinion polling in relation to those who would participate in the actual Labour Party leadership election of 2020, it is also worth identifying opinion towards the candidates within the wider electorate: after all, the Labour Party are selecting a new party leader in order to broaden their electoral appeal. Although no opinion-polling data was made available on the question of which candidate was the most unifying, data was available in terms of the other two measures within the Stark model-i.e. perceptions of electability and competence.

Table 5 below identifies the wider electorates' views of the candidates' electability. Starmer was the candidate the wider electorate were most likely to vote for, but not by much. Starmer was the candidate most likely to retain the votes of those who had voted Labour at the General Election of 2019. Most significantly, Starmer was the candidate who was most likely to secure the support of centrist Liberal Democrat voters (which totalled around 3.6 million at the General Election of 2019). A total of $50 \%$ of Liberal Democrat voters indicated that they were more likely to vote Labour under Starmer (and 46\% unlikely), but the feedback on Long-Bailey was significantly worse-19\% more likely and 75\% unlikely (Ipsos, 2020). 
Table 5 Voter preferences and the Labour Party leadership candidates 2020

\begin{tabular}{lllll}
\hline & \multicolumn{2}{l}{ General election 2019 voter } & \\
\cline { 2 - 5 } & Total & Conservative & Labour & $\begin{array}{l}\text { Liberal } \\
\text { demo- } \\
\text { crats }\end{array}$ \\
\hline Starmer & & & & \\
Likely & 35 & 9 & 81 & 50 \\
Unlikely & 52 & 83 & 11 & 46 \\
Don't know & 13 & 8 & 8 & 4 \\
Net & -17 & 74 & +70 & +4 \\
Long-Bailey & & & & \\
Likely & 28 & 3 & 73 & 19 \\
Unlikely & 60 & 90 & 19 & 75 \\
Don't know & 12 & 7 & 8 & 6 \\
Net & -32 & -87 & +54 & -56 \\
Nandy & & & & \\
Likely & 32 & 10 & 76 & 31 \\
Unlikely & 53 & 81 & 14 & 57 \\
Don't know & 15 & 9 & & 12 \\
Net & -21 & -71 & & +26 \\
\hline Source & & & & \\
\hline
\end{tabular}

Source IPSOS (2020)

Table 6 provides the evidence of voter perceptions of the candidates and competence. The findings replicate those in relation to perceived electability in that Starmer were perceived to be the most favourable candidate amongst known Labour supporters and amongst known Liberal Democrat voters. Running parallel to the positive impression that Starmer made amongst Liberal Democrats-with a $+31 \%$ net rating on favourability - was the negative impression that Long-Bailey made with Liberal Democrat voters - she had a $-30 \%$ net rating on favourability.

Therefore, the Labour Party leadership election of 2020 demonstrates the ongoing relevance of the Stark model for analysing leadership selections in British political parties. The paper can make this claim not only on the basis of the preference that parliamentarians showed towards Starmer at the nomination stage but from insights from opinion polling of Labour Party members who participated in the leadership election. They voted for Starmer because they believed that he was the most acceptable candidate; the most electable candidate and the candidate most capable of being an effective leader of the Opposition and potentially Prime Minister. Using opinion polling from the wider electorate, the paper demonstrates the broad correlation between the opinion of the Labour Party membership, and the wider electorate, in relation to electability and competence. 
Table 6 Competence and the Labour Party leadership candidates 2020
General election 2019 voter

\begin{tabular}{lll}
\hline Total Conservative & Labour & Liberal \\
& & Demo- \\
& & crats
\end{tabular}

\begin{tabular}{lllll}
\hline Starmer & & & & \\
Favourable & 24 & 14 & 38 & 45 \\
Unfavourable & 22 & 42 & 8 & 14 \\
Don't know & 54 & 44 & 54 & 41 \\
Net & +2 & -28 & +30 & +31 \\
Long-Bailey & & & & \\
Favourable & 10 & 5 & 22 & 9 \\
Unfavourable & 31 & 48 & 19 & 39 \\
Don't know & 59 & 47 & 60 & 51 \\
Net & -23 & -43 & +3 & -30 \\
Nandy & & & & \\
Favourable & 13 & 11 & 21 & 22 \\
Unfavourable & 18 & 30 & 11 & 16 \\
Don't know & 68 & 59 & 68 & 63 \\
Net & 5 & -19 & +10 & +6 \\
\hline
\end{tabular}

Source YouGov (2020c)

\section{Conclusion}

This article used the Labour Party leadership election of 2020 to test the ongoing validity of the Stark model for explaining leadership election outcomes. It also used this as a means by which to engage with the debates that have opened up on bias within political science research in relation to political parties and political leadership. The article does not argue that such debates should not be engaged in. However, it does challenge the claims that Maiguashca and Dean (2020) have made with regard to the Stark model-i.e. that it lacks utility and objectivity.

On the first issue of its utility this article argues the following. Using either qualitative insights from interviews from within the campaign teams of the respective candidates or descriptive statistics from opinion polling about the candidates, academics have used the Stark model to reach judgements about which candidates were the most acceptable, electable and/or competent. Within studies on the Labour Party, there have been occasions when one candidate was felt to be the strongest candidate across all three criteria-e.g. the Labour Party leadership elections of 1963, 1976, 1988, 1992 and 1994. On other occasions, the best candidate across each of the criteria has been disputed: in these cases, the Stark model has emphasised the first-order criteria of acceptability, which explains the leadership election outcomes in 1980, 1983 and 2010. Overall, then, the Stark model has provided useful explanations into the outcomes of all leadership elections since 1963 with the exception of the selection of Corbyn (see Heppell 2010a, b; Heppell et al. 2010; 
Heppell and Crines 2011; Dorey and Denham 2011, 2016; Quinn 2012, 2016; Denham and Dorey 2018; Denham et al. 2020).

When broadening that out to leadership elections within the Conservative Party, it has contributed to explaining outcomes in all of their leadership election since 1963 with one exception: the selection of Thatcher in 1975. Taken together, the Stark model has been applied to 24 leadership elections across the two main parties between 1963 and 2020 and the criteria (and ordering) aid our explanations in all but the selections of Corbyn and Thatcher (see Heppell 2008; Denham 2009a, b, 2010, 2012, 2013, 2017; Quinn 2012; Jeffery et al. 2018; Denham et al. 2020).

That the selection of Corbyn was an exception, provided the basis for Maiguashca and Dean (2020) to critique the Stark model, but the selection of Starmer reaffirmed its explanatory value. This is explained in section three of this article, and the polling evidence provided in Tables 4-6 provides us with valid evidence in relation to which candidate was deemed the most acceptable, electable and competent. Moreover, the most recent Conservative Party leadership reaffirms its explanatory value as Boris Johnson was selected primarily as he fulfilled the first-order criteria of acceptability — as the lead Brexiteer Conservative in a party, especially at the membership level that believed in leaving the European Union (Jeffery et al. 2020).

On the second issue of objectivity, this article offers the following response. The argument being made by Maiguashca and Dean (2020) is that political science research on British politics and political leadership was characterised by biases against Corbyn, and it implied that the Stark model was reflective of those biases.

However, the argument that the Stark model is being used to demonise candidates of the left, like Corbyn, is undermined when we consider leadership selection studies within the Conservative Party, in which the selection of Thatcher is the only selection that the Stark model fails to explain. This could indicate that the Stark model struggles to explain the appeal of ideological candidates, but it cannot be used to argue that the Stark model specifically demonises candidates on the left alone. Therefore, it cannot be aligned to the biases against the left argument being advanced.

Furthermore, any suggestion that the Stark model tends towards centrist candidates-i.e. those tending towards the social democratic right or New Labour end of the ideological spectrum or towards the one-nation economically wet wing of the Conservative ideological spectrum-lacks sufficient supporting evidence. Such an implication can be challenged by the selections made by the Labour Party in the leadership elections of 1963, 1980 and 2010 in which the candidates that were closer to the social democratic wing-Brown, Healey and David Miliband-were all defeated, as argued by Heppell 2010a, b, Dorey and Denham 2011; see also Quinn 2012; Denham and Dorey 2018; Denham et al. 2020. It also lacks evidence in relation to previous Conservative Party leadership elections-e.g. candidates that were closer to the one-nation economically wet wing such as Michael Heseltine (in 1990) and Kenneth Clarke (in 1997 and 2001) have been defeated, with their defeats being in part explained by the criteria within the Stark model—see for example, Heppell 2008; Heppell and Hill 2008, 2010; see also Quinn 2012; Denham et al. 2020. Given that the Stark model has been used by academics to explain the selection of such ideologically diverse figures as Foot for the Labour Party in 1980, to 
the arch-Brexiteer Johnson for the Conservatives in 2019 , it is clearly not a model infected with an ideological bias.

Therefore, the question marks that have been placed against the Stark model in relation to its utility and its objectivity can be challenged. It remains a legitimate means by which academics can seek to explain leadership elections, and it has been used to explain the selection and rejection of an ideologically diverse range of candidates from within both the Labour and Conservative parties. Given that the Stark model aims to help explain who did win and why - and not who should have wonit should be detached from the critique that has been developing around biases within the scholarship of British politics and political leadership.

\section{References}

Alderman, K., and N. Carter. 1993. The Labour Party Leadership and Deputy Leadership Elections of 1992. Parliamentary Affairs 46 (1): 49-65.

Alderman, K., and N. Carter. 1994. The Labour Party and the Trade Unions: Loosening the Ties. Parliamentary Affairs 47 (3): 321-337.

Alderman, K., and N. Carter. 1995. The Labour Party Leadership and Deputy Leadership Elections of 1994. Parliamentary Affairs 48 (3): 438-455.

Alderman, K., and N. Carter. 2002. The Conservative Party Leadership Election of 2001. Parliamentary Affairs 55 (3): 569-585.

Allen, P. 2020. Political Science, Punditry and the Corbyn Problem. British Politics 15 (1): 69-87.

Allen, P., and D. Moon. 2020. Predictions, Pollification, and Pol Profs: The "Corbyn Problem" Beyond Corbyn. Political Quarterly. 91: 81-88.

Asthana, A. and H. Stewart. 2016. Labour MPs hostile to Corbyn named in leaked party document. The Guardian, 23rd March.

Bale, T. 2016. The Loser Takes It All. Labour and Jeremy Corbyn. Political Quarterly 87 (1): 18-19.

Bale, T., P. Webb, and M. Poletti. 2020. Footsoldiers: Political Party Membership in the 21st Century. London: Routledge.

Bennister, M., and T. Heppell. 2016. Comparing the Dynamics of Party Leadership Survival in Britain and Australia: Brown, Rudd and Gillard. Government and Opposition 51 (1): 134-159.

Bush, S. 2019. How Does the Labour Leadership Election Work. New Statesman, 13 December.

Bush, S. 2020. Why is the Labour Leadership Race Taking So Long? New Stateman, 24 February.

Cammaerts, B., B. DeCillia, and J-C. Magalhaes. 2020. Journalistic Transgressions in the Representation of Jeremy Corbyn: From Watchdog to Attackdog. Journalism 21 (2): 191-208.

Clarke, H., P. Kellner, M. Stewart, J. Twyman, and P. Whiteley. 2016. Austerity and Political Choice in Britain. Basingstoke: Palgrave.

Clarke, H., S. Ho, and M. Stewart. 2000. Major's Lesser (not Minor) Effects: Prime Ministerial Approval and Governing Party Support in Britain Since 1979. Electoral Studies 19 (2-3): 255-273.

Clarke, H., D. Sanders, M. Stewart, and P. Whiteley. 2009. Performance Politics and the British Voter. Cambridge: Cambridge University Press.

Clarke, H., and M. Stewart. 1995. Economic Evaluations, Prime Ministerial Approval and Governing Party Support: Rival Models Reconsidered. British Journal of Political Science. 25 (2): 145-170.

Cowley, P., and M. Bailey. 2000. Peasants' Uprising or Religious War: Re-examining the 1975 Conservative Leadership Contest. British Journal of Political Science 30 (4): 599-629.

Crines, A., D. Jeffery, and T. Heppell. 2018. The British Labour Party and Leadership Election Mandate(s) of Jeremy Corbyn: Patterns of Opinion and Opposition Within the Parliamentary Labour Party. Journal of Elections, Public Opinion and Parties 28 (3): 361-379.

Curtis, C. 2019. In Their Own Words: Why Voters Abandoned Labour. YouGov Polling https://yougov. co.uk/topics/politics/articles-reports/2019/12/23/their-own-words-why-voters-abandoned-labour

Cutts, D., M. Goodwin, O. Heath, and C. Milazzo. 2019. Resurgent Remain and a Rebooted Revolt on the Right: Exploring the 2019 European Parliament Elections in the United Kingdom. Political Quarterly. 90 (3): 496-514. 
Cutts, D., M. Goodwin, O. Heath, and P. Surridge. 2020. Brexit, the 2019 General Election and the Realignment of British Politics. Political Quarterly 91 (1): 7-23.

Denham, A. 2009a. From Grey Suits to Grass Roots: Choosing Conservative Leaders. British Politics 4 (2): 217-235.

Denham, A. 2009b. Far from Home: Conservative Leadership Selection from Heath to Cameron. Political Quarterly 80 (3): 380-387.

Denham, A. 2010. Hague Rules OK? Electing and Ejecting Conservative Leaders. Representation 46 (1): 81-89.

Denham, A. 2012. From Ted to Ed: Electing British Party Leaders. Political Quarterly 83 (3): 576-584.

Denham, A. 2013. From Coronations to Close Encounters: Party Leadership selection in British Politics. British Politics 8 (2): 164-180.

Denham, A. 2017. Choosing Party Leaders: Anglophone Democracies, British Parties and the Limits of Comparative Politics. British Politics 12 (2): 250-266.

Denham, A., and P. Dorey. 2018. Tales of the Unexpected: The Selection of British Party Leaders Since 1963. British Politics 13 (2): 171-194.

Denham, A., P. Dorey, and A. Roe-Crines. 2020. Choosing Party Leaders: Britain's Conservatives and Labour Compared. Manchester: Manchester University Press.

Denver, D., and M. Garnett. 2012. The Popularity of British Prime Ministers. British Journal of Politics and International Relations. 14 (1): 57-73.

Diamond, P. 2016. Assessing the Performance of UK Opposition Leaders: Jeremy Corbyn's Straight Talking, Honest Politics. Politics and Governance 4 (2): 15-24.

Dorey, P. 2017. Jeremy Corbyn confounds his critics: Explaining the Labour Party's remarkable resurgence in the 2017 Election. British Politics 12 (3): 308-334.

Dorey, P., and A. Denham. 2011. O, brother, where art thou? The Labour Party leadership election of 2010. British Politics 6 (3): 286-316.

Dorey, P., and A. Denham. 2016. The Longest Suicide Vote in History: The Labour Party Leadership Election of 2015. British Politics 11 (3): 259-282.

Drucker, H. 1976. Leadership Selection in the Labour Party. Parliamentary Affairs 29 (4): 378-395.

Drucker, H. 1981. Changes in the Labour Party Leadership. Parliamentary Affairs 34 (4): 369-391.

Drucker, H. 1984. Intra-Party Democracy in Action: The Election of Leader and Deputy Leader of the Labour Party in 1983. Parliamentary Affairs 37 (3): 283-300.

Fielding, S. 2020. Keir Starmer is Labour's continuity Miliband contender. The Spectator, 2 April.

Goes, E. 2020. Labour Campaign 2019: A Defeat of Epic Proportions. In Britain Votes: The 2019 General Election, ed. J. Tonge, S. Wilks-Hegg, and L. Thompson. Oxford: Oxford University Press.

Hayton, R., and T. Heppell. 2010. The Quiet Man of British Politics: The Rise, Fall and Significance of Iain Duncan Smith. Parliamentary Affairs 63 (3): 525-545.

Heppell, T. 2008. Choosing the Tory Leader: Conservative Party Leadership Elections from Heath to Cameron. London: IB Tauris.

Heppell, T. 2010a. Choosing the Labour Leader: Labour Party Leadership Elections from Wilson to Brown. London: I. B. Tauris.

Heppell, T. 2010b. The Labour Party Leadership Election of 1963: Explaining the Unexpected Election of Harold Wilson. Contemporary British History 24 (2): 151-171.

Heppell, T. 2010c. Labour Leadership Elections from Wilson to Brown: Ideological Factions and Succession Planning Strategies. Representation 46 (1): 69-79.

Heppell, T. 2020. The Starmer Era. Fabian Review. April.

Heppell, T., and A. Crines. 2011. How Michael Foot Won the Labour Party Leadership. Political Quarterly 82 (1): 81-94.

Heppell, T., A. Crines, and R. Nicholls. 2010. Ideological Alignments Within the Parliamentary Labour Party and the Leadership Election of 1976. British Politics 5 (1): 65-91.

Heppell, T., and M. Hill. 2008. The Conservative Party Leadership Election of 1997: An Analysis of the Voting Motivations of Conservative Parliamentarians. British Politics 3 (1): 63-91.

Heppell, T., and M. Hill. 2010. The Voting Motivations of Conservative Parliamentarians in the Conservative Party Leadership Election of 2001. Politics 30 (1): 36-51.

Heppell, T., and T. McMeeking. 2021. The Election and Re-election of Jeremy Corbyn as Leader of the Labour Party. In Corbynism in Perspective: The Labour Party under Jeremy Corbyn, ed. A. RoeCrines. Newcastle: Agenda.

Hickson, K., M. Beech, and R. Plant, eds. 2004. The Struggle for Labour's Soul: Understanding Labour's Political Thought Since 1945. London: Routledge. 
IPSOS. 2020. 'Political Monitor: Attitudes Labour Leadership Candidates. https://www.ipsos.com/sites/ default/files/ct/news/documents/2020-02/jan2020web2.pdf

Jeffery, D., T. Heppell, R. Hayton, and A. Crines. 2018. The Conservative Party Leadership Election of 2016: An Analysis of the Voting Motivations of Conservative Parliamentarians. Parliamentary Affairs 71 (2): 263-282.

Jeffery, D., T. Heppell, and A. Roe-Crines. 2021. The Conservative Party Leadership Election of 2019: An Analysis of the Voting Motivations of Conservative Parliamentarians. Parliamentary Affairs, forthcoming

Jobson, R., and M. Wickham-Jones. 2011. Reinventing the Block Vote? Trade Unions and the 2010 Labour Party Leadership Election. British Politics 6 (3): 317-344.

Johnston, R., C. Pattie, H. Pemberton, and M. Wickham-Jones. 2016. If You've Got Friends and Neighbours: Constituency Voting Patterns for the UK Labour Party Leader in 2010. Journal of Elections, Public Opinion and Parties 26 (1): 58-77.

Jones, A. 2020. Meet Lisa Nandy the No Nonsense Northerner. Daily Telegraph, 3 April.

Labour List. 2020. Rolling List: CLP Nominations in Labour's 2020 leadership race. https://labourlist. org/2020/01/rolling-list-clp-nominations-in-labours-2020-leadership-race/. Accessed 10 March 2020.

Labour Party. 2020a. Labour Party Leadership Nominations. https://labour.org.uk/people/leadership2020-nominations/leadership-2020/ Accessed 10 March 2020.

Labour Party. 2020b. Leadership and Deputy Leadership Election 2020-Results. https://labour.org. uk/people/leadership-elections-hub-2020/leadership-elections-2020-results/ Accessed 4 April 2020.

Maguire, P. 2020a. What Labour leadership candidates are telling the grassroots-and why. New Statesman, 16 January.

Maguire, P. 2020b. Keir Starmer: The Sensible Radical. New Stateman, 31 March.

Maiguashca, B., and J. Dean. 2020. 'Lovely People but Utterly Deluded' British Political Science's Trouble with Corbynism. British Politics 15 (1): 48-68.

Nandy, L. 2020. Labour's path back to power will be through on the ground activism. The Guardian, 3 January.

Pemberton, H., and M. Wickham-Jones. 2013. Brothers all? The Operation of the Electoral College in the 2010 Labour Leadership Contest. Parliamentary Affairs 66 (4): 708-731.

Philo, G., M. Berry, J. Schlosberg, A. Lerman, and D. Miller, eds. 2019. Bad News for Labour: Antisemitism, the Party and Public Belief. London: Pluto Press.

Quinn, T. 2002. Block Voting in the Labour Party: A Political Exchange Model. Party Politics 8 (2): 207-226.

Quinn, T. 2004. Electing the Leader: The British Labour Party's Electoral College. British Journal of Politics and International Relations 6 (3): 333-352.

Quinn, T. 2005. Leasehold or Freehold? Leader-Eviction Rules in the British Conservative and Labour Parties. Political Studies 53 (4): 793-815.

Quinn, T. 2010. Membership Ballots in Party Leadership Elections in Britain. Representation 46 (1): $101-117$.

Quinn, T. 2012. Electing and Ejecting Party Leaders in Britain. Basingstoke: Palgrave Macmillan.

Quinn, T. 2016. The British Labour Leadership Election of 2015. British Journal of Politics and International Relations 18 (4): 759-778.

Quinn, T. 2018. From the Wembley Conference to the McDonnell Amendment: Labour's Leadership Nomination Rules. Political Quarterly 89 (3): 474-481.

Quinn, T. 2019. The Conservative Party's Leadership Election of 2016: Choosing a Leader in Government. British Politics 14 (1): 63-85.

Rea, A. 2020. Jess Phillips's Exit is a Lesson in the Limits of 'Straight-Talking' Politics, New Statesman, 21 January.

Roe-Crines, A., T. Heppell, and D. Jeffery. 2021. Theresa May and the Conservative Party Leadership Confidence Motion of 2018: Analysing the Voting Behaviour of Conservative Parliamentarians. British Politics, forthcoming

Russell, M. 2021. Brexit and Parliament: The Anatomy of a Perfect Storm. Parliamentary Affairs, forthcoming

Sjöblom, G. 1968. Party Strategies in a MultiParty System. Lund: Studentlitteratur.

Stark, L. 1996. Choosing a Leader: Party Leadership Contests in Britain from Macmillan to Blair. London: Macmillan. 
Stewart, M., and H. Clarke. 1992. The (un)importance of Party Leaders: Leader Images and Party Choice in the 1987 British Election. Journal of Politics 54 (2): 447-470.

Stevens, D., J. Karp, and R. Hodgson. 2011. Party Leaders as Movers and Shakers in British Campaigns? Results from the 2010 Election. Journal of Elections, Public Opinion and Parties 21 (2): $125-145$.

Syal, R., F. Perraudin, and N. Slawson. 2016. Shadow Cabinet Resignations: Who Has Gone and Who is Staying. The Guardian, 27 June.

Walker, P. 2020. 'Make-or-break time' on antisemitism in Labour, says Lisa Nandy. The Guardian, 9 February.

Whiteley, P., H. Clarke, D. Sanders, and M. Stewart. 2013. Affluence, Austerity and Electoral Change in Britain. Cambridge: Cambridge University Press.

Whiteley, P., M. Poletti, P. Webb, and T. Bale. 2019. 'Oh, Jeremy Corbyn!' Why did Labour Party Membership soar after the 2015 General Election. British Journal of Politics and International Relations 21 (1): 80-98.

Wickham-Jones, M. 2014. Introducing OMOV: The Labour Party-Trade Union Review Group and the 1994 leadership contest. British Journal of Industrial Relations 52 (1): 33-56.

YouGov. 2020a. 'Labour Members Opinion', April $3^{\text {rd }}$. https://docs.cdn.yougov.com/m3og65nsmm/ RLB_LabMembers_Feb20.pdf

YouGov. 2020b. 'Labour Members Opinion. https://d25d2506sfb94s.cloudfront.net/cumulus_uploads/ document/f34qa8dfwf/InternalResults_200225_LabMembers.pdf

YouGov. 2020c. Favourability Labour Leadership, April 2 ${ }^{\text {nd }}$. https://docs.cdn.yougov.com/8v60g6ztyw/ Internal_Favourability_200402_LabourLeadership.pdf

Publisher's Note Springer Nature remains neutral with regard to jurisdictional claims in published maps and institutional affiliations. 